DOI: https://doi.org/10.30837/MMP.2021.042

\title{
SOCIAL AND LABOUR FEATURES OF ENTREPRENEURSHIP ACTIVITY: STRATEGIC ASPECT
}

Iastremska O.

The section considers the peculiarities of the use of human capital in entrepreneurial activities, modern features of the formation and support of social and labour relations. It is proposed as their basis to use an organizational culture, which consists of a culture of contracts and a culture of joint actions. As the main types of culture contracts are allocated: lobbying, active (infrastructural), corrupt, fairway (redistribution), transformational. The culture of joint actions is aimed mainly at the internal environment of the enterprise, focused on the staff, its personal characteristics, individual and group needs. Types of contract culture are dependent on the types of strategic management centers and the criteria of which are proposed to be used to motivate managers of different levels of management.

Keywords: social and labour relations, organizational culture, culture of joint actions, culture of contracts, motivation, strategic centers of management.

\section{INTRODUCTION}

Effective activity of enterprises depends on many factors, among which in modern conditions, the vast majority of practitioners and scientists distinguish correctly formed social and labour relations. This determines the objective need for further research of the peculiarities of the course of entrepreneurial activity on the basis of rational use of human capital, organizational culture and its components, depending on the composition of managers, their characteristics, methods and styles of management used.

Analysis of the results of enterprises of different industries makes it possible to conclude that there are certain differences in their management depending on the formed organizational culture in the internal and external environments. Its existence is confirmed by a number of studies that have a social orientation and strategic context. Therefore, there is a need for additional research of these important problems in the present, since their existence does not allow to fully use the available 
labour potential of employees at enterprises in accordance with their qualifications and representation in the total number of personnel, which reduces the efficiency of its work. Therefore, existing developments on these problems require further development both theoretically and practically.

\section{THE USE OF HUMAN CAPITAL IN ENTREPRENEURIAL ACTIVITIES}

The driving force of economic development is the innovative nature of entrepreneurship. One of the directions of government policy of the state in the economic sphere is focused on the development of small and medium-sized businesses through the liberalization of the regulatory regime (licensing, permitting and controlling activities, etc.) and the introduction of minimal regulation of business activities, the application of the declarative principle in the process of business, the transition from direct subsidization to financial and credit support for small and medium businesses through partial compensation from the budget of interest rates on bank loans [20]. In recent years, more and more attention has been paid to improving the regulatory framework for promoting the development of entrepreneurship in Ukraine. Much attention is paid to the problem of entrepreneurship development in scientific research, in particular A. Smith, R.Cantilion, J. Schumpeter, 3. Varnaliy, D. Bogynya, L. Vorotin, V. Geyts, V. Kolot, V. Sizonenko, O. Savitsky and other scientists. These publications consider various aspects of entrepreneurial activity: theoretical and organizational problems, state regulation of entrepreneurship development, connection with the process of formation of the middle class, motivational mechanisms of entrepreneurial activity. Despite the extensive research of domestic and foreign scientists, the theory, methodology and mechanism of promoting the development of entrepreneurial activity, the social aspects of entrepreneurship, the use of human capital of the population in entrepreneurial activity are not paid enough attention.

R. Apresyan considers entrepreneurship as a socio-organizational and transformative activity, which is a kind of creativity and in this sense is one of the 
key forms of social activity in general [2]. The authors of the scientific study [1] define entrepreneurship as a special, creative type of economic behavior, which forms the necessary basis for achieving economic success. A. Shapiro notes that in almost all definitions of entrepreneurship, we are talking about such behavior, which includes an element of the initiative; organization or reorganization of socioeconomic mechanisms, in order to be able to benefit from the available resources and specific situation; taking responsibility for a possible failure, that is, the willingness to risk [15]. This definition combines economic, personal and managerial approaches. Taking into account the social and economic aspects of the above definitions, it is advisable to highlight such provisions through which entrepreneurship deserves attention:

- due to the entrepreneurial activity of the population is provided with quality goods and services, while the main stimulus of the entrepreneur is his own economic interest;

- entrepreneurial activity acts as the main mechanism for ensuring employment and reducing unemployment of the country's population;

- the introduction of entrepreneurial activity in all spheres of human activity provides prerequisites for the formation of a competitive economy of Ukraine;

- business entities replenish the country's budget;

- entrepreneurship is capable of innovation and risk at its own expense, and entrepreneurs are a powerful engine of innovative development in various spheres;

- entrepreneurship is the main source of formation of the middle class in the country [20, p. 101].

Thus, based on the provisions presented, it can be argued that the phenomenon of entrepreneurship requires detailed analysis not only in the economic, political aspects, but, which is especially important, and in the socio-cultural.

Modern economic conditions, characterized by a high degree of independence of the functioning of individual entrepreneurs, as well as the wide introduction of market relations in the process of interaction of all production and economic systems, cause the need for a more complete and effective use of their existing potential in 
order to increase the economic level of the development of society as a whole. Achieving this goal depends primarily on the three most important components: substance production conditions, personal production conditions (educational and cultural level of employees) and their combination in the process of work. At the same time, the role of a personal factor in interaction with substance factors of production is especially growing. In the course of entrepreneurial activity, its participants enter into certain social relations, that is, relations regarding their organizational position, image and way of working life, as well as the conditions for the formation and development of the individual [16]. They are manifested in establishing communication links between participants of entrepreneurial activities and in determining their organizational position, which directly affects the formation of interests and behavior of individual groups of employees, as well as the results of their activities. How harmoniously social entrepreneurial relations fit into a complex macro system of market, environmental, political and other relations depends on the success, stability and perspective of entrepreneurial activity.

In the process of doing business, the main functions of the entrepreneur should be the ability to innovate and productive use of capital. In modern conditions, income can be obtained not only from production, commodity or cash capital. On this ground, the theory of human capital appeared, and among the factors of production that create income, began to include creative, entrepreneurial, human abilities. The authors of the concept of "human capital production" treat human capital as a stock that produces labour services in standard units of measurement and consists of the qualities and abilities of the person involved in the production of human capital itself, and that part of human capital, whose services are offered in the market to the employer and which is an investment in the production of other objects and services [20, p. 101]. In the context of this theory, a scientific study [4] hypothesizes the merger of "labour" and "capital" in the process of creative activity. It is this merger that should be considered the basis of the emergence of the theory of labour capital, the implementation of which is able to ensure the productive use of the labour potential of an economically active population in market conditions 
Labour theory K. Marx essence of economic relations between workers and capitalists reduced to alienation and exploitation of labour capital. It defines labour as a form of commodity that belongs to the free person of the hired worker and is alienated from the employee by its purchase and sale on the market, takes the form of variable capital and belongs to the capitalist as an integral part of the aggregate capital [20, p. 102]. In this context, O. Buzgalin notes a stable relationship: the more innovative the potential of employees is developed, the more they are able to implement management functions as an unchecked creative activity [4]. That is, the exploitation is removed by itself as the creative content of the work develops. An employee performing creative functions is inherently able to perform and functions characteristic of the entrepreneur, in particular the functions of managing the public process of production. In the post-industrial economy, human capital weighs more than money, technology or other resources embodied in physical capital in the form of industrial, commercial, banking or financial capital. The use of human capital in entrepreneurial activities to date has not been paid enough attention. In the concept of entrepreneurial management, the position of which is used by developed countries, the organization is considered as a community of entrepreneurs. In such organizations, a new type of manager is formed - a manager-entrepreneur. Managers should consider each employee, subordinate as an entrepreneur, capable of creative work, the result of which should be innovation. In the situation of entrepreneurial management, every employee of the organization, despite the position, tries to improve skills, develop professional abilities. Therefore, human capital in the process of entrepreneurial activity receives a motive for self-growth [20, p. 102-103].

The modern level of development of productive forces, industrial relations, and the formation of the foundations of information society in the context of globalization is objectively determined by the main element of effective production of human goods and services, its mental and physical potential, its expanded reproduction. Such a process will take place and dynamic movement with the primary creation of appropriate conditions for the genesis of domestic human capital at both micro and macro levels. The growth of the role and importance of human 
potential in the formation of information society necessitates the establishment of an adequate economy, where the defining role will belong to intellectual labour potential. In this regard, it is legitimate to ask questions about the formation of the economy of human capital, the development of scientific and theoretical foundations of its formation, justification of recommendations for the introduction of competitive organizations of different levels into the practice [20, p. 92].

In modern economic theory, the concept of human capital is widely used in the study of industrial relations, the development of socio-economic systems [20; 3; 8; 10]. Each scientific school gives its essential characteristic of this concept, its vision of its place and role in the system of economic categories. According to the authors of scientific research [20, p. 92 - 93], human capital must be investigated both from the side of productive relations and production. In the first case, human capital is the reserves of mental and physical energy, their use in the process of life, expanded reproduction of opportunities for work, especially entrepreneurial activity, in the process of the genesis of the economic system. Human capital on the part of production relations expresses relations between people about the effective formation, distribution, exchange and use of labour potential, property relations on the elements of reproduction in order to ensure comprehensive human development, increase productivity, family income.

An important element of the theory of human capital economics is that it involves a free person who has the opportunity to make his own choices in a multiaspect market space. In this regard, human education, labour productivity and income can be expressed in the form of such interdependence: investment in human capital (in particular, in education) - the formation of human capital (increasing the quality of labour potential) - the result of labour activity (increasing productivity) - salary or profit as an expression of the market value of the use of human capital [20, p. 93].

During the 20th century, the productivity of physical labour increased 50 times. But on this, the potential for its increase has exhausted. In the 21st century, the main factor is increasing the productivity of mental labour. Its representatives in developed countries are already outnumbered by other workers. Thus, in the United 
States at the end of the 20th century, they made up almost $40 \%$ of the country's workforce [20, p. 94]. The analysis of economic activity of employees of entrepreneurial structures in Ukraine allows to identify three main behavioral types in the field of labour. The first behavioral type is business-oriented workers, which would allow them to realize their abilities and achieve material well-being. The second behavioral type is the orientation of employees to conscientious fulfilment of their duties without any special manifestations of initiative. The third type is when employees are profit-oriented without much effort. It is about those who are not interested in what they are doing and who do not have a desire for a career [9]. The future of the national economy will depend on productivity, first of all, representatives of the first group. In the conditions of the formation and development of the market economy, there is a gradual transition from hierarchical management with a rigid system of administration to relationships that take into account the growth of the role of the worker's personality in the process of labour. In this regard, management must be built on the knowledge of its motivational settings, the ability to form and direct them in accordance with the tasks of the enterprise. Therefore, there is an objective need to develop new approaches to prioritizing values and changing the concept of personnel management of enterprises, the main thing in which workers (in the internal environment) and consumers of products (in the external environment). It should be borne in mind that personnel as a management object have their own specific features, namely:

1) people have their own interests, needs, will, goals, react differently to managerial actions;

2) their management is carried out in the conditions of complex interaction of individual, group and collective goals;

3) high level of uncertainty of the controlled environment, and hence the degree of risk of managing it;

4) in addition to scientific approaches, intuition and partial case are of great importance in personnel management. 
As the main functions of social management of entrepreneurship, which is precisely the influence on the behavior of staff, it is necessary to highlight the following: satisfaction of the interests of staff (increasing the level of their wages, professional growth, career movements, solving social problems); determining the need for personnel; provision of personnel; organization of the labour process; stimulation of staff work; evaluation of personnel use; career guidance of workers; recruitment and recruitment; labour adaptation; business evaluation of personnel during reception, certification, selection; creation of working conditions; motivation of work activity and personnel behavior; professional development of personnel; social development of personnel; labour movements; insurance; conflict and stress management $[16 ; 6]$.

One of the most important problems of the formation of the human capital economy is the implementation of an expanded reproduction of domestic managersentrepreneurs, people who would always be in an active creative search for ways to increase production efficiency, able to work with subordinates, and not only perfectly know the modern economy. The presence of such intellectual labour potential is primarily determined by the talent for this complex work, and by the system of continuous learning throughout the whole process of life [20, p. 94].

The poor quality of human capital may become in the future the main obstacle to the economic development of Ukraine, because investments in human capital are extremely small, and the economic policy sector is aimed at the old technological institutions of industrial society. Education expenditures in the mid-1960s accounted for $5 \%$ of GDP, and today they make up a little more than 3\% (however, with the simultaneous growth of private investments). It should be noted that, for example, in the EU countries this figure is twice as high [20, p. 94-95].

It should be emphasized that the main purpose of investments in human capital, from the human point of view, is to increase personal income, which should be a natural result of investments in their education, vocational training, health, culture. Personal development requires considerable time and material resources, but 
then these assets, like physical capital, should provide a person with higher and more stable income [20, p. 95].

It is necessary to develop an appropriate system for stimulating both hired workers and employers to continuously improve knowledge and professional skills at the state level. Everyone should not only theoretically, but also necessarily know and feel in practice how simple work differs from complex work. Workers who do work that require greater mental and physical energy are expected to receive wages or profits many times higher. Appropriate stimulation systems should be aimed at achieving optimally high final results of economic activity of each organization [20, p. 95].

In Ukraine, the process of de-qualification of labour potential continues. The number of employees who upgrade their skills was in 2004 about $8 \%$ of the average number of employees. Extremely low amounts of funding for professional training of hired employees demonstrate data on labour costs: the average monthly cost of professional training of one employee is $1.9 \mathrm{UAH}$, which is slightly more than $0.3 \%$ of total labour costs [20, p. 95]. Employers are practically not responsible for ensuring the proper level of qualification of their employees. The long-term state policy on the development of the national labour potential has not been formed; there are no forecasts on the demand for professions and the development of their content. The problem of professional education in production remains difficult. The average frequency of professional development of employees is once every 12 years. Therefore, it is urgent to form in Ukraine systems of continuous training of personnel throughout the labour life. To do this, it is necessary to improve the regulatory and legal framework for professional training of personnel, including directly in production [20, p. 96].

The future of Ukraine is primarily connected with the development of human capital. To get on the trajectory of sustainable economic development, it is necessary to accumulate creative, intellectual forces, to identify gifted youth who are able to quickly and constructively respond to the requirements of time, and to help them master modern knowledge. The need to create a qualitatively new social and 
psychological climate that would contribute to socio-economic innovations and greater self-realization of a person in our country, the development of the human capital economy [20, p. 98-99].

In developed countries, investments in human capital are growing at a particularly rapid rate. In the United States in 1970 - 1990 biennium human capital increased faster than physical capital. In addition, already in 1990 total expenditures on education, health and social security in this state exceeded production investments more than three times [20]. According to the calculations of the famous American theorist E. Denison, investment in human capital gives a return of 5 - 6 times more than investment in material production. The World Bank, on the example of a survey of 192 countries, concluded that only 16\% of economic growth in transition economies is due to physical capital, $20 \%$ - natural capital, the rest $64 \%$ are associated with human and social capital [20, p. 94].

The effectiveness of investing in human capital is an integral condition for the formation of a competitive economy of countries with a market economy. This is especially important for Ukraine in the development of market relations, where the decisive role belongs to entrepreneurial activity, because at all levels of management in our society there has still not been a reorientation of priority to the human factor of economic growth in relation to material and material.

The specificity of human capital and investments invested in it is primarily due to the fact that it cannot be formed without direct participation of its owner, this applies to both material costs and time and mental and physical energy. The effectiveness of investing in the future is explained not only by obtaining certain "dividends" in the form of experience, professionalism, high qualification of the person, but also material return on him (wages, profits, income as a whole). In this regard, investing in human capital is a prerequisite for the growth of its labour potential at any level. Professional training, even in the absence of material expenses that can be financed by the state or the enterprise, that is, to be free of charge for the consumer, but it requires time and difficult work from it [20, p. 107]. 
According to the authors of the scientific research on the socio-economic problems of entrepreneurship development [20, p. 107 - 108], the analysis of the effectiveness of investments in human capital at the enterprise level begins with the assessment of the costs for them and the expected benefits from their implementation (fig. 1.1).

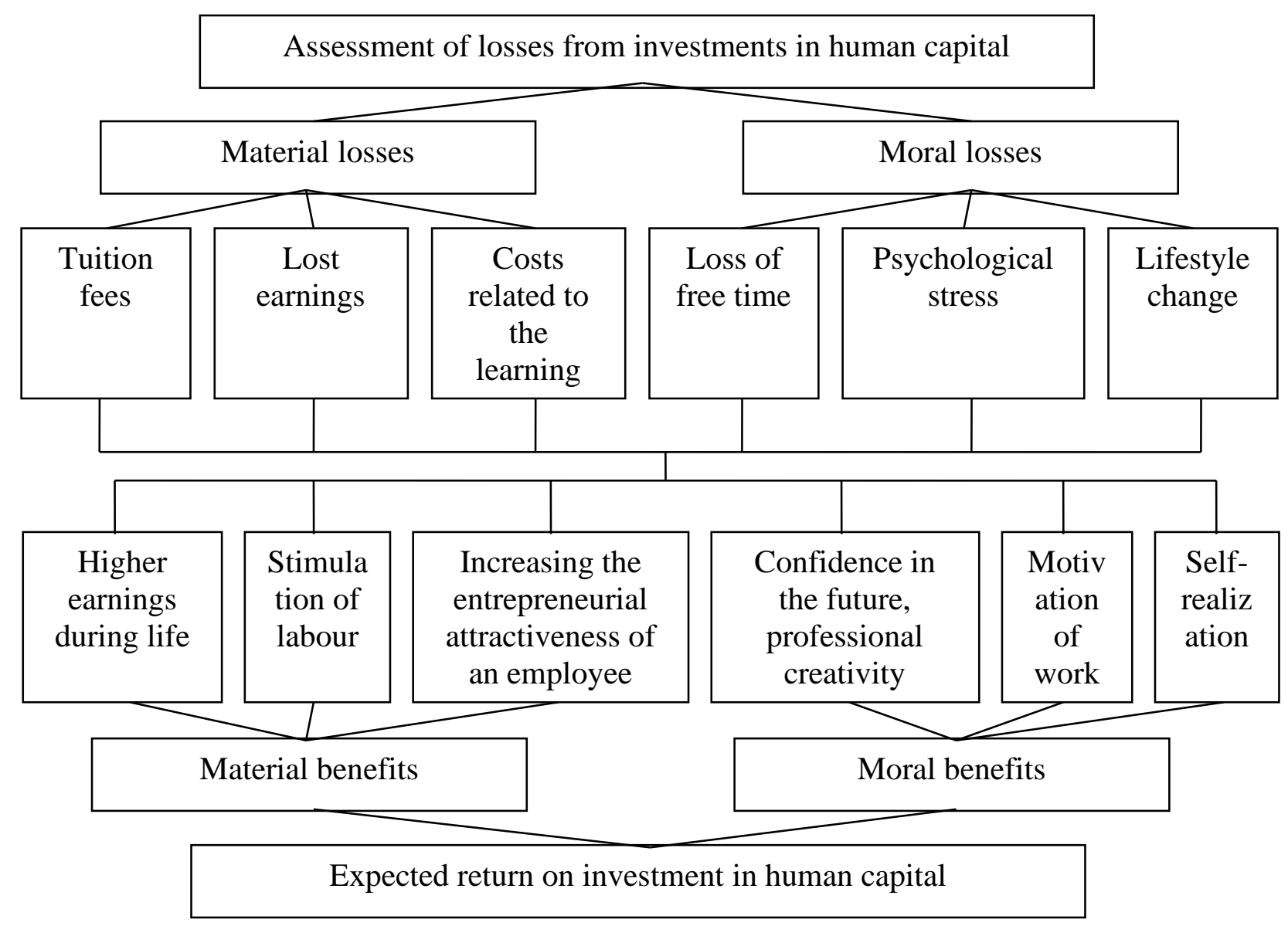

Fig. 1.1. Analysis of the effectiveness of investments in human capital

The costs associated with investments in human capital can be conditionally divided into two groups: material and moral. Accordingly, the expected return on investment in education also consists of material and moral benefits. Material costs can be calculated, and moral estimates are quite difficult because of the individual characteristics of each person. However, it is the moral features of investing in human capital that play a significant role. As for the expected return on investment in human 
capital, quantitatively determining the projected return is quite difficult. After all, the return occurs only with a certain time lag, which is a deterrent for investors who want to make investments and almost immediately get their "dividends" [20, p. 108].

As a rule, researchers of investment efficiency in the field of human capital turn to the technique of analysing "cost-benefit" [7]. The essence of this method is to compare the value of benefits and the value of costs and their cost estimation, taking into account the time factor (it is first necessary to bring these two indicators to one point in time, applying the discounting method). If the current cost of benefits overlaps expenses, investment can be considered profitable. This analysis of the effectiveness of investment projects regarding human capital can be used by all investment entities. Of course, any calculations cannot be accurate and common to everyone. This is especially true for the effectiveness of investing in human capital. After all, the production activity involves not knowledge as such, but specific living and very different people, whose level of education is only approximately reflected in diplomas, certificates and duration of training and the intensity of the use of existing knowledge depends on a set of socio-economic motivating and demotivating factors. Therefore, it is necessary to distinguish between the task of economic assessment of human capital and investment in it, on the one hand, and the task of creating organizational, economic and social conditions for its effective use on the other [20, p. 108-109].

In the UK in 1991, the project "Investments in People" was introduced, which proved itself an important initiative in approving those enterprises that invest in the training of their employees. The program provides employers with a national standard for analysing preparation needs, and companies wishing to be recognized as investors must meet this standard. This helps to maximize business efficiency by connecting the training and development of employees with the goals of the organization. The standard is based on four basic principles:

- top manager takes measures to develop all employees to achieve business goals; 
- the employer regularly reviews the purpose of its business and plans to achieve it through the development of the skills of individual employees and teams;

- the employer is engaged in the preparation and development of people all the time, while they work, from the moment of recruitment;

- the employer calculates investments in training and development and assesses the impact of training on improving production efficiency [20, p. 109].

Achieving a sufficient level of productivity, and therefore quality and competitiveness, mainly depends on entrepreneurial structures. It is necessary to realize that the main and decisive efforts should be carried out at enterprises. First of all, we are talking about the reorganization of the enterprise management system, an integral part of which should be the subsystem of management of productivity and quality of human capital. Important attention in this case should be paid to the policy of training and professional development of personnel, taking into account the following principles [6]:

1. Higher management of the enterprise should be directly involved in the education process. Managers should be competent, as each of them is responsible not only for their official growth and their professional qualities, but also for the development of human resources. The role of the manager is to help and support employees, as well as to encourage the acquisition of new knowledge.

2. It is necessary to create special training programs in accordance with the general strategy of the business entity. At the same time, it is possible to organize training in two ways: horizontal (training in certain issues of different subdivisions) and vertical (training in certain issues of a particular unit, including management).

3. The result of the training is subject to careful assessment. The priority qualitative benchmarks in this case are professionalism (ability to understand in special areas), communication (ability to use new forms of communication, listen to and understand the interlocutor, use business terminology), technical skills (ability to work with new equipment, new software).

In the process of learning, it is necessary to create conditions that would allow us to unlock and develop human potential. Therefore, it is necessary to use interactive 
forms of teamwork of those who learn, thereby creating an atmosphere in which people try to learn from each other, exchange practical experience, and strengthen informal contacts.

An important aspect of the problem of effective use of human capital in entrepreneurial activities is also the creation of programs and methods to improve the quality of work life. High quality of work life is characterized by the following: work should be interesting; performers must receive a fair reward and recognition of their work; supervision by the management should be minimal, but always carried out when it is necessary; performers must participate in making decisions that affect their interests and related to their work; must be provided with a guarantee of work.

The current state of the economy of Ukraine requires the development of scientific and theoretical foundations of the economy of human capital, where it would be assumed that the evolutionary way of radical reforms in the existing economic system. The emphasis should be focused on the expanded reproduction of domestic human capital, and especially managers-entrepreneurs who carry out the process of effective production of goods and services, which will allow to ensure the proper level of welfare of the population, comprehensive human development.

According to the modern new entrepreneurship paradigm, which is focused on the human industry [16], the enterprise is a place where it gets the opportunity to meet its interests and needs. The dynamism of modern processes determines the mobility of all business entities. This requires a person to be highly qualified and mobility. A new style of management gives the worker freedom of action, releases initiative and creative opportunities. This approach in management is implemented by forming an appropriate entrepreneurial culture.

\section{ENTREPRENEURIAL CULTURE: CONTENT, FUNCTIONS, MODERN FEATURES}

The phenomenon of entrepreneurship culture takes a special place in the concept of entrepreneurial society. Considering entrepreneurial activity as a process carried out by individuals, enterprises or organizations regarding the development of 
natural resources, production, purchase, sale of goods or the provision of services in exchange for other goods, services or money, it should be borne in mind that this process should end with the mutual benefit of business partners. Moreover, this process, at whatever practical level it exists, is closely related to the cultural environment consisting of an external culture (society) and the internal culture of business partners. As business partners can act as private entrepreneurs, and firms, organizations. Business relationships, conducting commercial operations are carried out with certain structures, subjects of market relations, which also have a certain level of business culture. Such institutions contain banks, wholesale and market sellers, specialized firms and institutions (legal, accounting, audit, etc.), educational institutions, marketing firms, advertising agencies, transport agencies, insurance companies, utilities, suppliers, communications and information, etc. In this regard, the level of the culture of entrepreneurial activity acts as an integrated factor of business efficiency. The phenomenon of culture can have a direct, often the most unpredictable impact on the result of business, achieving its intermediate and final goals. Thus, the formation of entrepreneurial culture is one of the most important long-term strategic tasks of both entrepreneurs and the state in the construction of civilized market relations.

The term "culture" refers to the most ambiguous concepts. Famous German psychologist R. Rüttinger notes: "Not only to observe and analyse the culture, but also to understand it means to grab hold of the cloud first. Culture and its associated perceptions of values are not rigid concepts, such as organization of structure and process, managing political and business directions of strategy and budgets. Culture is the softest material of all that exist. But "soft" is "solid" on thriving enterprises [18]. This remark can be extended to the macro level, that is, the culture of entrepreneurship.

In the scientific literature there is no single definition of the concept of "culture of entrepreneurship". Some researchers understand under the culture of entrepreneurship a system of symbols, ceremonies and myths that inform members of the organization important ideas about values and beliefs, others - a more or less 
stable conjuncture of forces that prompts the entrepreneur to specifically respond to certain circumstances [14]. According to V.G. Makeeva, the culture of entrepreneurship is a set of patterns of behavior, value system, social norms, fundamental principles and social institutions that focus subjects on certain forms of economic activity in the system of entrepreneurship, which ensure the transfer of accumulated experience and contribute to the stability of entrepreneurship in time [14, p. 12]. Kredisov V.A. believes that entrepreneurial culture is a complex of interacting factors, including the experience of the past and present time, structural characteristics, the views of managers, rules and norms of economic behavior of entrepreneurs [12, p. 168]. Gitelman L.D. considers entrepreneurial culture as a set of values, beliefs, attitudes, as well as the general moral climate that help employees understand the purpose of the organization as a whole, the mechanism of its functioning and thereby create norms of activity and behavior, the rules of following them [5, p. 76]. Thus, the culture of entrepreneurship reflects the level of development of entrepreneurial activity, attitude to the legality, to the quality of products, to financial and production obligations, to the dissemination of business information, to the employees of the enterprise, etc. Given the above definitions, it is advisable to highlight such components of the content of the concept of "culture of entrepreneurship":

1) the entrepreneur's understanding of business values (each entrepreneur in a certain way sees the goals of the business and has his own scale of values, according to which he judges about consumers, customers, the needs of his product, the quality of the goods, the expected income);

2) rules and norms of behavior in the planning and implementation of business activities arising from ideas about business values (maintaining contacts with customers, identifying their desires, actively offering the goods they need, aftersales service);

3) specific behavior of the entrepreneur, during which he in practice implements the rules and norms of cultural behavior [14, p. 12-13]. 
According to R. Ryvkina, the culture of entrepreneurship should be considered in the field of its intersection with economic culture. The author gives the following definition of economic culture: "For all the features of economic cultures of different countries, the same structural patterns are preserved everywhere. For example, economic culture is always and everywhere a kind of intermediary between the complex of political, legal, economic and other conditions of a country and the economic behavior of subjects of its economy. It will not be an exaggeration to say: the development of the economy is a total result of the actions of millions of people, regulated by both the external institutional conditions of their activities and the peculiarities of the economic culture of the people themselves [17]. Three main functions of market culture are distinguished in the scientific literature, which are essentially related to the prerequisites for the emergence of a culture of entrepreneurship [17; 18]:

1) with the help of economic culture, values and norms necessary for the development of the economy are chosen or strengthened, traditions are accumulated;

2) on the basis of economic norms and values, accumulations of economic experience and transfer to new generations occur;

3) new forms of economic culture and new principles of management are formed at leading enterprises.

It is the successful implementation of the third function of economic culture that depends on how purposefully the economic and social systems stimulate the development of entrepreneurship, its culture and ethical norms. At the same time, ethical norms of doing business can never be imposed on such independent subjects of economic relations as entrepreneurs. They are produced gradually and are determined by practical realities - the need to increase the viability and long-term competitiveness of the enterprise.

The most fully entrepreneurial culture is characterized by the following functions:

- protective (serves as a kind of barrier to penetration of undesirable trends and negative values characteristic of the external environment); 
- communicative-integrative (provides survival in this socio-economic environment, stability and stability);

- regulatory (includes informal, unwritten rules that indicate how entrepreneurs should behave in the process of carrying out their activities);

- conservative (creates forces of internal stability and resistance to external influences by representing traditional samples of entrepreneurial work);

- adaptive (facilitates the mutual adaptation of workers to the organization and organization of workers);

- developing (related to the educational, educational effect, resulting in an increase in human capital, that is, increasing the knowledge and skills of workers, which the company can use to achieve its goals);

- broadcast (transmits information as a whole);

- innovative (contributes to the creation of new samples, more adapted to the changed circumstances);

- quality management (contributes to improving the quality of goods and services of the business entity, producing a more attentive attitude to work);

- orientation to consumers (takes into account the goals, requests, interests of consumers, which contributes to establishing more stable and consistent relations of the enterprise with customers);

- evaluating (creates methods and criteria for assessing actions, thus forming a regime of regulated and ranked behavior);

- goal setting (forms reference, idealized values that act as incentives and goals for the formation and selection of goals in entrepreneurial activities);

- reproductive (preserves and reproduces values of different shapes and types, passes them from generation to generation) [14; 13].

The process of emergence, formation and development of the culture of entrepreneurship is very complex. The formation of the culture of entrepreneurship is based on such basic principles [22, p. 168]: 
1. The principle of consistency defines the treatment of culture as a system of interconnected elements, the change of which is possible only by changing each element.

2. The principle of complexity determines the consideration of culture, taking into account the influence of psychological, social and organizational and economic factors.

3. The principle of nationalism implies the formation of a culture of taking into account national features, mentality, customs of the region, the country in which the organization is located and the subject of entrepreneurship.

4. The principle of historicity determines the need for conformity of the system of values of the organization and practice of interpersonal relations with the basic modern human values, as well as taking into account their dynamics in time.

5. The principle of science assumes the need to use scientifically grounded methods and solutions in the formation of a culture of entrepreneurship.

6. The principle of value orientation, that is, the basic orienting role of the value system for the whole system, which determines the culture of entrepreneurship.

7. The principle of scenario, that is, the presentation of all recommendations that determine and regulate the relations and actions of the staff of the organization in the form of a scenario that describes the content of the activities of all its employees, attributes to them a certain character and style of behavior.

8. The principle of efficiency assumes the need for a purposeful influence on the elements of the culture of entrepreneurship and its attributes in order to achieve the best socio-psychological conditions of the organization's personnel and its success in entrepreneurship.

According to R. Ruttinger [18], the process of emergence and formation of the culture of entrepreneurship and so-called subcultures (its variants and varieties) has the following prerequisites: 
1) a certain culture or subculture occurs after a certain time in any association of people;

2) each culture forms unwritten norms and mutual expectations that affect the behavior of the team and individual individuals. In this connection, culture can be characterized as the basis of adopted norms of behavior, which a group of people with a common past conveys to new members of the group by language and infant means;

3) people are more willing to develop and form the culture of the group, which they are members of, and not only passively perceive and reflect the culture due to the formed traditions.

According to the authors of the scientific work [11] L. Kolesnikova and V. Perekrestov, the development of culture forms a circle of norms and rules formed at micro and macro levels (fig. 2.1). In this model of the process of emergence and development of the culture of entrepreneurship, researchers consider the culture of market relations and culture in a broader context as a result of summing up millions of behavioral characteristics at the micro level, which in turn are determined by the level of development of the culture of entrepreneurship and the culture of society at the macro level. In turn, the cultures of individual organizations form a holistic phenomenon that characterizes a specific system of norms and rules or culture of interaction between organizations, characteristic of this particular area, region and country as a whole, forming what is called the culture of market relations and the culture of entrepreneurship. In reality, the culture of entrepreneurship is not a monolithic phenomenon. Within this process, various subcultures develop, and informal ones develop along with formal norms. At the same time, acting as part of an economic culture, it does not correlate with it as a part of the general, but rather permeates it through, being inherent in other elements of a broader system - the general culture of society, which includes the spheres of law, politics, religion, morality, art and science [11]. 


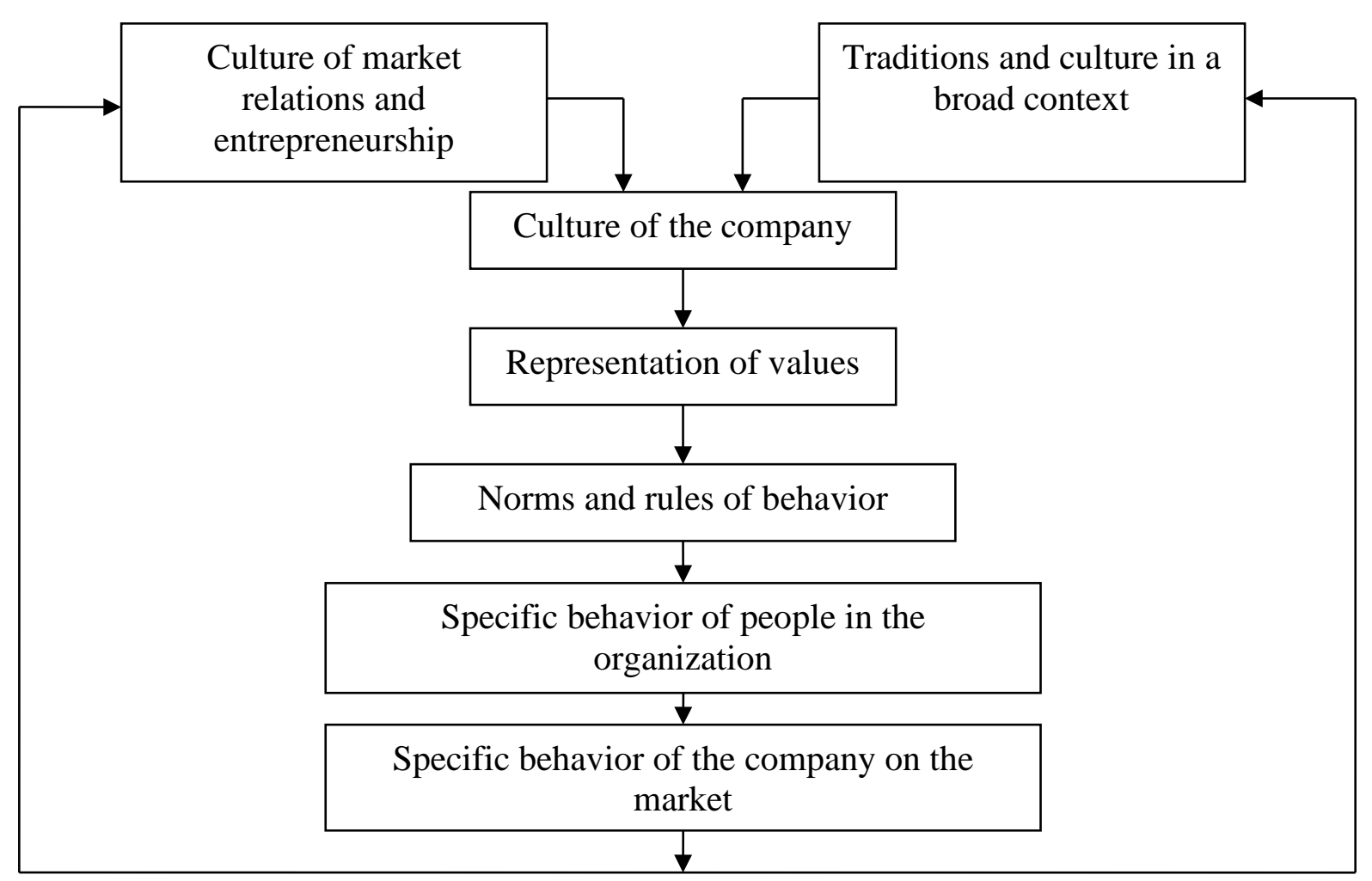

Fig. 2.1. Emergence and development of entrepreneurship culture

As the main stages of the process of formation of the culture of entrepreneurship, it is advisable to highlight the following:

1. Collection of data describing the state of the main elements of the external and internal environment of a particular organization.

2. Qualitative analysis of the degree of progressiveness of the main elements of the culture of entrepreneurship, their compliance with the signs of progressive culture (description of the practice of relations in the organization: employees with each other, employees and managers, personnel to their organization and external business entities; analysis of the real possibilities of entrepreneurial culture to meet the requirements arising from its functional role to create conditions for highly effective creative work, for social and psychological comfort, to ensure social partnership of staff and with the external environment).

3. Establishing a list of measures necessary to form a progressive culture of a particular object. 
4. Justification and design of each event.

5. Substantiation of design parameters of each event on transformation of elements of the existing culture of entrepreneurship.

6. Implementation of proposals for the formation of a progressive culture.

7. Analysis of the effectiveness of the proposed measures.

The tasks of the formation of the culture of entrepreneurship are given in fig. $2.2[22]$.

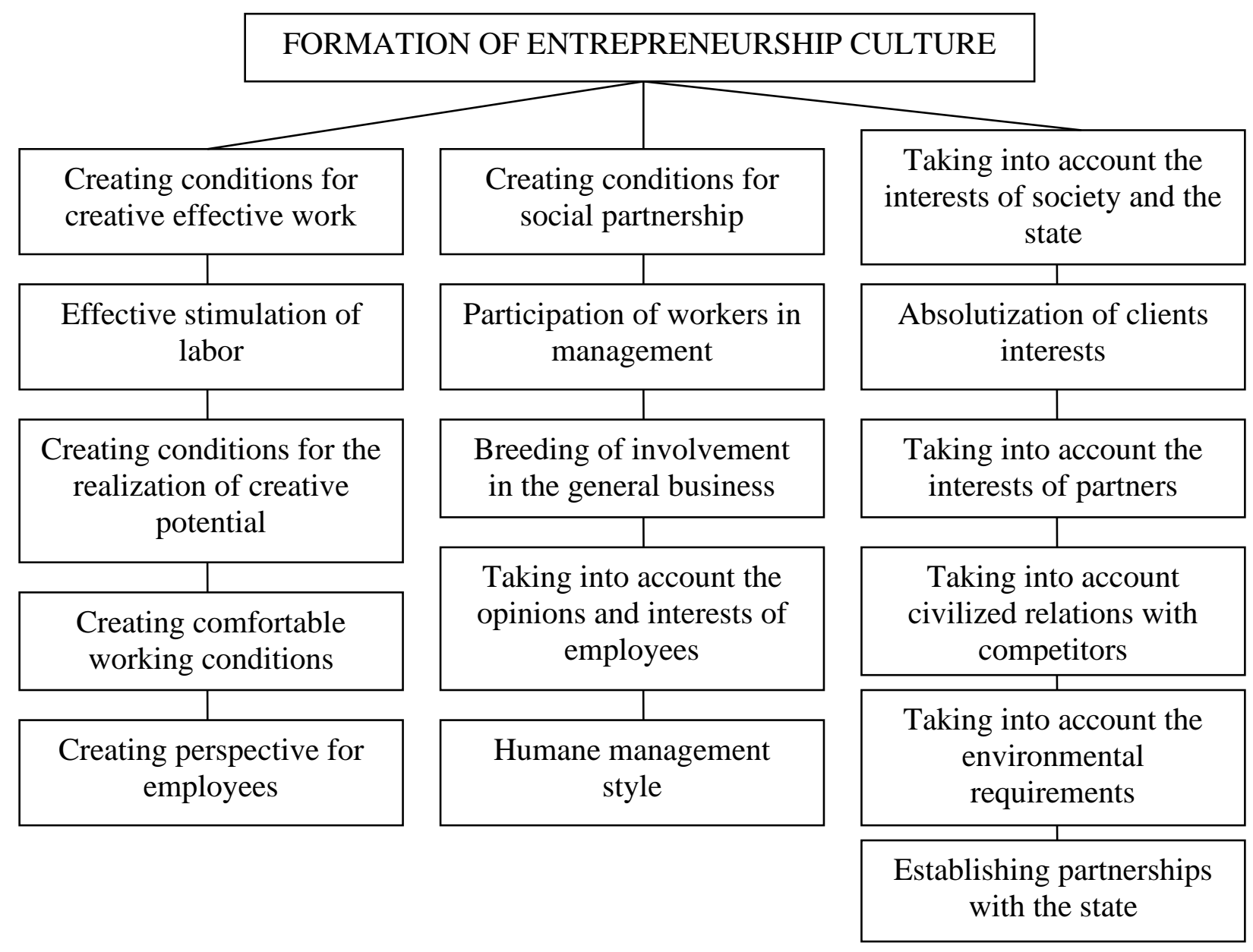

Fig. 2.2. The task of formation of the culture of entrepreneurship

Entrepreneurial culture is not a separate and closed body. The process of development of the culture of entrepreneurship is influenced by a number of factors.

1. State system, the type of economic system in the state, the level of liberality, predominant form of ownership. 
2. Universal values. General ideas about the meaning of life, about the place of a person in the universe and its purpose, about nature, duty, the desire for justice - all this affects economic activity, and therefore the development of the culture of entrepreneurship.

3. National-cultural and religious-cultural stereotypes of the way of life of a particular country. Cultures of different countries that form different systems of values significantly affect the culture of entrepreneurship and ultimately on the behavior of entrepreneurs. One culture approves of riskier behavior, the other - more cautious. In some cultures, the process of solving means more than the result. Some cultures encourage a firm and unambiguous position in decision making, while others value a tendency to compromise.

4. Cultural examples of economic ideas and economic behavior. In one society, the attitude to technology, even in the areas necessary for the survival of people, is quite restrained, and in the other - much attention is paid to the constant improvement of technology and technology.

5. Norms and patterns of interaction between business entities, methods of reproduction and translation of these models, i.e. rules of conduct of a certain business professional group (traders, financiers, industrialists).

6. Value-motivational attitude to labour, wealth, accumulation (work ethic). The dominance of commercial and financial intermediary activity over production, the departure of national wealth abroad - all this is a destabilizing factor in the development of entrepreneurial culture.

7. Spatial factor - features of the landscape, climate, location of the country, size of the general and agricultural territory.

8. Environmental dynamics [14; 5; 13; 24].

The research conducted in the 80's of the 20th century by Dutch scholarsociologist Herbert Hofsted, has proved a role of national-state and ethnic factors in the development of entrepreneurial culture. Hofsted built a four-component model of values that allows describing the types of cultures of entrepreneurship [14; 13; 
22]. According to this model, entrepreneurial culture can be characterized by the following components.

\section{Distance of power.}

The "distance of power" component determines the degree of encouragement of inequality in the distribution of power among members of cultural community. The distribution of power in culture essentially provides a balance of forces seeking greater inequality and forces fighting for its reduction. The consequence of inequality is a divergence in the social status of individuals, welfare, power, rights. In the culture of entrepreneurship with a small distance of power, the concept of "welfare", "authority" and "power" evoke positive associations and are a consequence of the individual's personal abilities, rather than his belonging to a certain group. The "distance of power" factor also affects management activities in organizations. Thus, managers of enterprises where the distance of power is insignificant, often use democratic or liberal management styles, do not recognize strict control over the actions of subordinates [14, p. 26-27].

2. Indicator of avoidance of uncertainty.

The "avoidance of uncertainty" component shows the degree of perception and reaction of culture to the uncertainty and complexity of the surrounding world. If, for example, uncertainty does not cause strong fear and concern, then such an entrepreneurial culture is characterized by emotional openness to external changes and high readiness for risk. In this case, hope for success, self - confidence, not fear of possible difficulties and losses, and prevail. The influence of the component "avoidance of uncertainty" on entrepreneurial activity is manifested in insignificant structuring of tasks, a small number of written prescriptions, a flexible management style [14, p. 27-28].

\section{Individualism - collectivism.}

The component "individualism - collectivism" shows the degree of integration of individuals into a group (cultural community). Individualistic culture emphasizes the importance of personality, its interests and well-being. In a collectively oriented culture, all aspirations are aimed at satisfying group interests. Such a culture is 
dominated by a sense of duty towards a collective, group or partner of a higher rank. The actions and thinking of an individual are more determined by belonging to a particular group, the relationship from which is built, as a rule, on a moral basis. In such a culture, the group cares for its members, and they, in turn, give all their strength to its benefit. The policy of organization with collectivist culture is based on the principles of loyalty and sense of duty [14, p. 28-29].

4. Masculinity - femininity.

The component "masculinity - femininity" reflects the tendency of the bearers of cultural community to adhere to the "masculine" or "feminine" style of behavior, due to the traditional notion of the social role of man and woman. The desire for social contacts, care, improving the quality of life - all these are characteristics of the "female" style of behavior. In business organizations, where the "male" style prevails, a strong focus on success, more importance is given to the interests of the organization and there is a tendency to an authoritarian method of decision making $[14$, p. 30].

In the development of the theory of G. Hofstede V.V. Tomilov determined the dependence between the type of organizational structure of the subject of entrepreneurship and the type of entrepreneurial culture according to the component "masculinity - femininity" (table 2.1) [22].

Thus, the process of formation of culture is influenced by many factors, and each country has its own priorities: religious or national aspect, socio-economic or political processes, etc. Given this, we can conclude that the culture of entrepreneurship is part of the socio-cultural system. Entrepreneurship is carried out to meet the needs of people living in a particular society that forms their basic views, values and norms of behavior. Ignoring these realities is impossible, so success or failure in entrepreneurship directly depends on how fully the factors of the sociocultural environment are taken into account (ethical and religious norms: worldview, morality, religious views, beliefs; cultural principles and values: national culture and art, customs and traditions, attitude to cultural and historical heritage; lifestyle: life goals and values, behavior, relationships, consumer priorities) in the activity of the 
enterprise. Since the process of development of society is evolutionary, the culture of entrepreneurship develops together with the evolution of economic, social, cultural realities. However, the full identity between the development of the culture of entrepreneurship and the history of society cannot be. Having arisen and started to form under certain conditions, entrepreneurial culture becomes a fairly autonomous system that develops according to its internally determined laws. External influences can only stimulate the development of the culture of entrepreneurship in one or another direction, encourage it to adapt to changing circumstances. At the same time, the culture can be greatly modified: on the basis of old ideas, new, more adapted to the changing circumstances, more appropriate to certain needs of business entities.

Table 2.1

Organizational structures of enterprise management taking into account the type of entrepreneurial culture

\begin{tabular}{|c|l|l|l|c|c|}
\hline No. & $\begin{array}{c}\text { Type of } \\
\text { organizational } \\
\text { management } \\
\text { structure }\end{array}$ & $\begin{array}{c}\text { Organizational } \\
\text { form of } \\
\text { management }\end{array}$ & $\begin{array}{c}\text { Type of } \\
\text { entrepreneurship }\end{array}$ & $\begin{array}{c}\text { Strong } \\
\text { culture } \\
\text { (male" } \\
\text { style) }\end{array}$ & $\begin{array}{c}\text { Weak } \\
\text { culture } \\
\text { ("female" } \\
\text { style) }\end{array}$ \\
\hline 1 & Linear & $\begin{array}{l}\text { Individual- } \\
\text { private, corporate }\end{array}$ & Small business & + & - \\
\hline 2 & Functional & Corporate & $\begin{array}{l}\text { Small, medium } \\
\text { business }\end{array}$ & - & + \\
\hline 3 & $\begin{array}{l}\text { Line-staff } \\
\text { (divisional) }\end{array}$ & Corporate, state & Medium business & - & + \\
\hline 4 & Linear-functional & $\begin{array}{l}\text { Individual- } \\
\text { private, state }\end{array}$ & $\begin{array}{l}\text { Medium, big } \\
\text { business }\end{array}$ & + & + \\
\hline 5 & Matrix & Shareholder, state & $\begin{array}{l}\text { Medium, big } \\
\text { business }\end{array}$ & - & + \\
\hline 6 & Network & Shareholder, state & $\begin{array}{l}\text { Medium, big } \\
\text { business }\end{array}$ & - & + \\
\hline
\end{tabular}

Based on the peculiarities of the process of formation and development of entrepreneurial culture, the following properties should be distinguished: 
1) generality - the ability to cover all kinds of actions carried out by business entities, that is, entrepreneurial culture is the form in which economic acts are enshrined;

2) informality - the lack of connection between the functioning of entrepreneurial culture and the official rules established by the order, that is, entrepreneurial culture acts in parallel with the formal economic mechanism;

3) accumulativeness - the propensity of carriers of the culture of entrepreneurship (cultural community) to the perception of ever invented ways and objects of activity;

4) modification - the ability to enrich or update their cultural traditions in order to adapt to the external environment and internal integration;

5) effectiveness - the ability to function productively due to more carriers of culture and due to their energy;

6) ambivalence - the ability of regulators of the culture of entrepreneurs to call out the duality of experiences, which allows to use the norms and values of culture on the principles of free choice;

7) stability - the ability of the formed values of culture and ways of their implementation to acquire the character of traditions and to maintain stability for several generations [14, p. 22; 13, p. 55-56].

The culture of entrepreneurs, their business ethics is also manifested in relations with society, which is determined by participation in solving economic, social and environmental problems. The problem of social responsibility of entrepreneurs in modern society is of increasing importance [23]. There is no single content of social responsibility for all entrepreneurs. Without taking into account the legal provisions in the field of social responsibility its content, each business entity can determine in its own way. The content of social responsibility differs depending on the characteristics of business entities, namely: their size, manufactured goods, competitive strategies, production processes, marketing methods, goals, 
managers, etc. Despite the fact that social responsibility has different content and forms for individual industries and entrepreneurs, the main obligations exist for all entrepreneurs - these are obligations of entrepreneurs in relation to society, which extend to many areas. Saniakhmetova highlights the following basic requirements of social responsibility of entrepreneurs in modern society:

- increase the efficiency of entrepreneurs (to be more efficient and progressive, to produce the best goods and services, to guarantee the quality of consumer goods);

- full responsibility of business entities to interested groups of persons (shareholders. workers);

- greater responsibility of entrepreneurs for the welfare of the whole society [19].

Social responsibility of entrepreneurs is becoming increasingly important in Ukraine, as entrepreneurs are becoming an increasingly influential force in society during the development of market conditions of management. Entrepreneurs should not only strive to achieve the goal of profit, but also anticipate high standards of social responsibility. The formation of a new strategic thinking of entrepreneurs is necessary, that is, the formation of entrepreneurial culture in accordance with the basic values of society. It is also advisable to provide certain measures of encouragement that stimulate social responsibility of entrepreneurs.

Makeeva V.G. has developed a model of socially oriented entrepreneurship (fig. 2.3). In this case, social policy is considered by the author as a complex of socially responsible measures in the field of investment and employment, production, environmental protection, management, marketing. The purpose of social policy is to ensure that entrepreneurs by their activities contribute to the reduction of social contradictions, negative consequences of the market economy (unemployment, poverty, etc.) [14, p. 118]. 


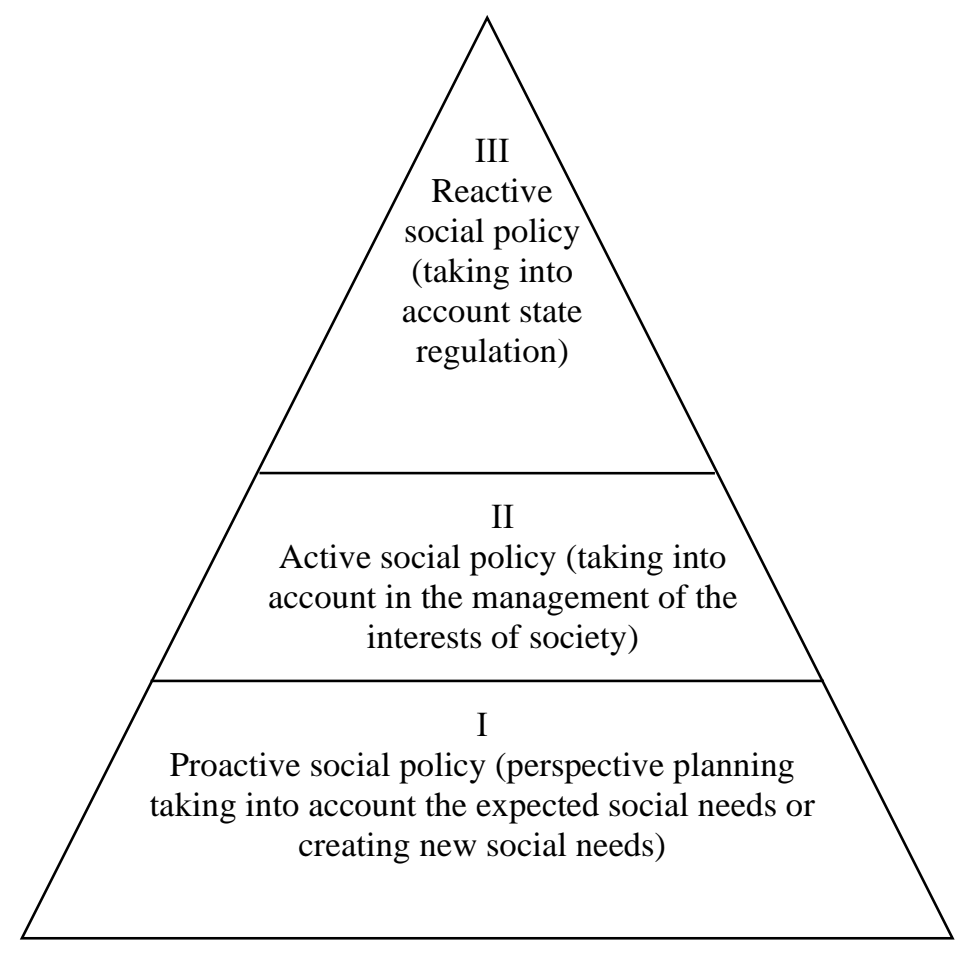

Fig. 2.3. Model of socially oriented entrepreneurship

Reactive social policy assumes that an organization as an economic integrity is obliged to take care only of the effectiveness of the use of its resources. Thus, Nobel Prize winner M. Friedman noted that the real role of business is to use its energy and resources in activities aimed at increasing profits, provided that it adheres to the rules of the game and participates in open competition without running to fraud. Thus, an entrepreneur has the right to ignore the negative social effect that his activities can carry out on consumers and society, to make decisions, guided only by the goal of maximizing profit. Realizing the function of the owner, the entrepreneur must provide the greatest return on the resources used and will seek to maximize income. But on the other hand, as a business owner, seeking to ensure the long-term stability of the enterprise, he is forced to form his goals taking into account external influences. In this regard, at the second level of hierarchical needs, in addition to economic responsibility, the organization takes into account the human and social aspects of the impact of its business activity on employees, consumers, local communities, suppliers, information facilities, unions, associations. This multilayer 
environment can greatly influence the achievement of the organization's goals, so entrepreneurs have to balance economic goals with the economic and social interests of these components. As a rule, the transition from reactive to active and further - to proactive social policy is carried out with the growth of the organization, due to the increase in resources and management experience. The proactive social policy is dominated by the strategic idea that the enterprise is prosperous to the extent that it is trusted by different members of society, as far as it takes into account their interests and rights in its policy [14, p. 118-119]. Thus, the real social responsibility of entrepreneurs lays, first of all, in such an organization of business that would provide employees with a stable property position, social protection the opportunity to receive education and spiritual growth.

The formation and functioning of modern entrepreneurial organizations is based on their openness and social orientation. Each subject of market relations solves independently the issues of not only internal organization (microlevel of entrepreneurial culture), but also organization of the whole set of connections with the external environment (macro level of entrepreneurial culture). The success of solving these problems depends on the efficiency of business activities. Based on such provisions, a new managerial paradigm is also needed, which, as Drucker emphasized: a) is aimed at a person, in order to make people capable of effective joint actions; b) inseparable from culture; c) forms communication between people; d) assumes that the evaluation of managers cannot be limited only to production indicators, it must be multi-sided [25]. Thus, the new management paradigm significantly increases the importance of entrepreneurship culture.

The advancement of science and technology, the widespread introduction of information and telecommunication technologies dramatically changed some features of the production process and its socio-cultural environment, caused significant changes in the culture of entrepreneurship. The transition to modern forms of production and management imposes on entrepreneurs such requirements, which can only meet the, who perceived and learned new cultural features. Therefore, in modern society, the question arises about the need for the formation of a specific 
post-industrial culture of entrepreneurship. As the main features of such a culture, it is advisable to highlight such as:

1. In the XXI century, the values and regulatory system of entrepreneurship culture are complicated. Thus, modern entrepreneurial culture gradually makes its object a reasonable attitude to nature, that is, there is a culture of environmental activity of the entrepreneur.

2. In a post-industrial society, the main value is a person with his knowledge, qualifications, creativity, and skills. The post-industrial culture of entrepreneurship is associated with the change in the basic motivations of activity and the emergence of a new content of professional work - from abstract activity and the way to make money; it began to gradually turn into a form of self-expression. A person treats the profession as an opportunity to realize creative, personal potential.

3. Globalization processes lead to the establishment of a new form of social organization based on information cultural stereotypes. Increasing the economic significance of scientific and information products has generated a new scheme of economic relations: fundamental scientific research - creation of technological and technical innovations - production of goods and services on the basis of advanced technologies - distribution of goods and services. Socio-cultural, political, economic conditions require reorientation of entrepreneurs on innovation, continuity of educational process in their activities [14, p. 20 - 21].

In recent years, in developed countries, the transition to a qualitatively new type of economic growth, which is called scientific-technical or innovative. It is characterized by: mass creative activity that changes the attitude to the forms of personality expression, risk, initiative, search; entrepreneurial behavior aimed at mastering high technologies; modification of property relations in large corporations; transforming nature of management. Accordingly, the entrepreneurial culture also changes. In this regard, it is necessary to strengthen the innovative components of entrepreneurial culture, characterized by a much higher educational level of entrepreneurs, creative environment, innovation, constant improvement, experimentation, readiness for risk, dynamism. According to Yu. V. Taranukha 
[21, p. 83], an innovative type of entrepreneurial culture due not to the internal evolution of the organization. On the contrary, the transition to flexible, open organizations was a reaction to changes in the conditions of entrepreneurship. In the XIX and early XX centuries, ensuring mass demand for standardized products was a defining feature of farming. Under these conditions, only industry determinism, product specialization and rigid management structures could ensure a reduction in production costs as a decisive tool of competition. Changes that occurred later in the nature of demand - deepening differentiation of demand and the transition to its individualization - required an approximation to the needs of the consumer, which led, in turn, to a shift in the accents of competition in the field of non-price competition. Finding competitive advantages became possible only through a flexible response to market challenges. There was a need for flexible, open to the perception of market changes of the organization. This required not only the flexibility of management, but also the democratization of the entire entrepreneurial process, that is, a change in the culture of entrepreneurship.

The culture of entrepreneurship manifests itself in the ability of organizations to rebuild their work on the basis of feedback. These transformations must correspond to the image of "civilized entrepreneurship." Today, at the level of household consciousness, there is still such an opinion in Ukraine that under market conditions, speculation is a type of legal entrepreneurial activity. Formally, Ukrainian entrepreneurs are focused on Western style of business relations. But in real behavior often demonstrate the so-called patriarchal tendencies [9]. To prevent these trends, first of all, it is necessary to change the conditions in which entrepreneurial activity is carried out, since the absence of a stimulating competitive environment is the main cause of the systemic crisis of the Ukrainian economy. The transformation of the culture of modern Ukrainian entrepreneurship into a civilized form should be carried out in the following areas:

1. Sovereignty of state and business (termination of opportunities to use power for business; limiting the state's ability to interfere in the economic activities of 
business entities; strengthening the financial independence of entrepreneurs by improving the macroeconomic conditions of its implementation).

2. Increase of competitiveness of markets (creation of favourable conditions for competitive activity by reducing industry barriers, development of market infrastructure, intensification of scientific and technical policy and optimization of foreign trade policy; active implementation of antimonopoly policy both regarding the restriction of monopoly manifestations and alignment of economic conditions).

Entrepreneurship undoubtedly plays an important role in the development of the economy and society. Thanks to the entrepreneurial initiative, new products and services are created, new ways of production and spheres of labour are introduced, new markets are opened. This indicates that entrepreneurship is not only a product of socio-economic development of society, but also requires constant and close attention to yourself from the latter.

Thus, the theoretical provisions considered allow to define the culture of entrepreneurship as a set of behavioral characteristics inherent in both individuals and organizations or local economic systems. It characterizes their ability according to personal, organizational or systemic self-renewal. At the personal level, the culture of entrepreneurship is determined by psychology, sensations and perception, the system of human values, at the organizational and systemic levels - the structure and quality of horizontal and vertical ties.

According to some experts $[11 ; 9]$ today in our country created a specific market economy without competition, which is due to the lack of a real stimulating competitive environment, which, on the one hand, allows to enter the markets with minimal costs to new business entities, and on the other, forces non-competitive enterprises to leave the markets during bankruptcy procedures. The lack of a stimulating competitive environment is one of the fundamental reasons for the insufficient level of business development in Ukraine. This indicates the primary need to implement measures aimed at maintaining the stability of both the external and internal business environment. Particular attention in the study of the key problems of the internal environment deserves the effectiveness of the use of 
Economic resources, the leading role among which are played by workers, since they are simultaneously both resources that are under the influence of the management system, and themselves have an impact on the progress of the enterprise development processes. In this regard, there is an urgent problem to investigate the state of human resources, to distribute the investigated enterprises into groups based on the results of their use.

3. Recommendations on organizational and cultural support for the strategic reorganization of business activities at the enterprise in the strategic aspect

Entrepreneurial activity should be susceptible to organizational and cultural relations in the internal environment of the enterprise and to relations with the external environment. Organizational and structural relationships are an organizational structure that, despite its level of adaptability, has a rigid and firm formal basis (hard structure), then organizational and cultural relations, i.e. organizational culture (or simply culture) as a component of susceptibility has a soft and informal nature (soft structure), which consists of That is, the set of organizational and structural relationships and organizational and cultural relations characterizes the processes of institutionalization of entrepreneurship at the micro level.

In the process of implementing business strategies, business processes of the enterprise undergo certain changes, so the main goal of organizational culture is to promote their positivization, as a result of which business entities must receive a "new status quo." And in order to keep it for the required period of time, the company needs to pay constant attention to the development of constructive relationships between employees and between subjects of the external environment in order to achieve the stability of the functioning of the system "object - project - investor," increase its productivity and use of human capital as a leading production force, which is characteristic of post-industrial society. Becoming the way of its construction, social and economic relations in Ukraine at all economic levels, including microeconomic, however, as in European countries, will gradually become intangible, which is to prevail the goals of personal development and its creative 
manifestation both in production and in consumption, over the tasks of multiplying material wealth. Therefore, the importance of organizational culture to increase the efficiency of business processes of the enterprise in general and its entrepreneurial activity in particular is gaining more and more importance. As for the latter, the culture of doing business is of dual importance: first, it has a direct impact on the activity of investment processes, and secondly, it itself is the object of investment, since it requires financial support for its development and acquiring a sign of adequacy to the rapidly changing conditions for the functioning of business entities. In addition, organizational and cultural relations have a socio-economic nature, manifested in the culture of contracts; culture of joint actions of personnel and subjects of the external environment.

As for the latter, the culture of doing business is of dual importance: first, it has a direct impact on the activity of investment processes, and secondly, it itself is the object of investment, since it requires financial support for its development and acquiring a sign of adequacy to the rapidly changing conditions for the functioning of business entities. In addition, organizational and cultural relations have a socioeconomic nature, manifested in the culture of contracts; culture of joint actions of personnel and subjects of the external environment:

- lobbying, which is typical for large enterprises or for entrepreneurial structures that carry out socially or environmentally important activities for the development of the industry or territory and need to lobby their interests and take them into account in the contracts concluded;

- intensive entrepreneurial behavior is inherent in high-performance enterprises seeking to take the position of leaders and gain additional financial advantages. This behavior would be more correct to call the forehand, because it is characteristic of business entities seeking to make an economic breakthrough;

- active infrastructure behavior is typical for small and medium-sized business entities seeking to obtain investments for investment in the infrastructure direction of their business development;

- corrupt - can be inherent in enterprises of any type and is associated with a violation of the moral canons of doing business, which is a negative side of the 
manifestation of the culture of contracts;

- redistribution behavior is inherent in enterprises that are not effective enough and expect profitable contracts from highly profitable structures. This type of contract culture should be called fairy or niche, because such enterprises are satellites of large entrepreneurial contracts;

- transformational - characteristic of economic entities that are in a state of change of ownership, transition to the production of new products, which are inherent in strategic transformations. As for entrepreneurial activity, they are actively engaged in it, but not in order to have super profits, but in order to get out of the difficult economic situation, so their culture of contracts is directed to the survival of the latter and obtaining the necessary investment resources under any conditions.

In the process of investing, it is advisable to consider the culture of contracts as external, its core is obtaining investment resources from the environment, creating and successful functioning of the triple system "object - project - investor," so it basically has an orientation on efficiency and economic result based on rational needs and a limited-rational type of behavior. But the companion of economic efficiency is social achievements, which it is advisable to consider as an important and integral part of the investment results, which is a social and collective benefit.

The culture of joint actions mainly focuses on the internal environment of the enterprise, the focus on the staff, its personal characteristics, and the satisfaction of individual and group needs, and through them - on achieving the expected economic results of entrepreneurial activity. Therefore, its basis is social needs, which are predominant, but in today's conditions are not prevalent, because the low level of material support of most hired workers still provides for the satisfaction of not only social, but primarily economic (rational) needs that are individualistic.

Since the implementation of the formed strategies of entrepreneurial activity of the enterprise is usually associated with carrying out, to a greater or lesser extent, strategic organizational transformations, which it is advisable to carry out through a network of strategic business centers (SBCs), the peculiarities of the culture of joint actions should be the following:

- prevalence of common organizational and cultural relations of enterprises 
that perform a unifying function and have the highest value priority;

- each type of SBC is inherent in its own culture of actions and internal relations in accordance with the level of independence, which it is endowed with a central control unit;

- the culture of joint actions of each SBC should not contradict the general culture of the enterprise, but be its integral derivative part.

Organizational and cultural relations, regardless of the level of hierarchy at which they appear and act, act in two forms:

- internal in the form of beliefs, moral attitudes, ways of thinking and values;

- external, which is transmitted through customs, traditions of the enterprise or SBC, group beliefs, rites, symbols.

The core of culture is the values from which the mission, the system of goals, the tasks of the enterprise. An important point is that its common values do not contradict the personal values of the members of the team, which determine their behavior in specific situations. Therefore, the main purpose of creating and using a culture inherent in a particular enterprise is to harmonize the interests and goals of personnel with the mission, their integration and adaptation to the rapidly changing environment in accordance with the general economic, competitive and functional strategies of its development.

The study of the formation and implementation of a culture of joint actions was paid attention to many researchers [1 - 12]. The vast majority of researchers consider organizational culture through a value system [16; 25]. By summarizing the proposals of most researchers and agreeing with the concept of culture as an integral characteristic, the type of enterprise culture can be represented as a system of common values, which include:

- norms of relationships and behavior of staff;

- appointment of the business entity;

- employees' perception of common goals;

- value benchmarks (care for staff, guaranteed employment, fair rewards, etc.);

- image, both general and investment attractive. 
Organizational culture influences the choice of a way to comprehend the surrounding reality and internal relations, regulates not only working relations in the team, but also has a certain impact on personal relationships of employees in their spare time, is reflected in the strategies and structure of the enterprise, the principles of management, which, in turn, are considered as tools of organizational culture.

Since functions are an expression of the essence of any phenomenon, the culture of an enterprise should be considered through their aggregate. Analysing the research of scientists on the list of functions $[14,13]$, considering their aggregate in the context of this study, it is advisable to dwell on the following list:

- integrative, the purpose of which is to harmonize the interests of the subjects of the internal environment of the enterprise with each other and with the external environment in the process of implementing business strategies as part of a set of strategic alternatives;

- regulating, which is to adjust the behavior of personnel in accordance with the general values of the enterprise, strategic and tactical goals;

- professional and educational, which provides for the promotion of a constant increase in the level of professionalism of employees of the enterprise, which is the key to achieving the set strategic goals;

- educational, according to which the behavior of the personnel of the enterprise acquires an effective moral and ethical content and direction.

All the proposed functions are simultaneously aimed at both the internal environment of the enterprise and the external one, as they allow to predict its behavior, which contributes to the formation of the subjects of market and powerstate relations of an active desire to cooperate with it. These functions also characterize micro-level processes of institutionalization of the enterprise and contribute to its established development in the chosen strategic direction.

The organizational culture of joint actions is formed, on the one hand, as an objective result of many years of experience of the enterprise in successfully solving business problems, which is fixed in its organizational structure and management processes, and on the other - as a subjective result of the active influence of management style, power installations of managers-leaders. It is found in the existing 
priorities of solving social problems; readiness for reasonable risks and innovations; using group forms of decision-making; focus on collective incentives; existing at the enterprise level of self-government, self-planning, self-organization, self-control and self-assessment of both individual subdivisions - SBCs and employees.

The company should not adhere to a single type of organizational and cultural relations during its life cycle, they must be changed synchronously to fluctuations in the priorities of the entity regarding its interests in the internal and external environments, which will increase the susceptibility of the enterprise to socioeconomic changes, one of the types of which is the proposal of investment projects. At the same time, the process of developing cultural relationships should be controlled by top managers. The impact of organizational culture on the management system is carried out through strategies and the general concept of management, decision-making models, the limits of the distribution of power, methods and tools for assessing the results of work and behavior of personnel.

Since it is advisable to use a network of SBC in the organization of its activities to gain some flexibility in accordance with the changing environment, each of them, depending on its type, should be inherent in its type of organizational culture. You can recommend the use of the following types of crops interaction centers with the central control unit (CU):

- for dependent SBCs (discretionary, maintenance, implementation), that is, centers of the first kind, - bureaucratic;

- for SBC relative to independent (expenses, income, profit), that is, the second type, - organic;

- for SBC of the third kind, independent (capital investments, venture capital, investments), - entrepreneurial;

- in general, for the enterprise in the process of forming and implementing strategies, - participative.

Thus, cultures of individual strategic units together form a holistic phenomenon characterizing a specific system of norms and rules or culture of interaction between subdivisions (joint actions), characteristic of a particular entity. The process of life of each proposed type of organizational and cultural relations. 
Regarding the investment of entrepreneurial activity, the basis for the formation of an effective organizational culture should be investment transparency: internal contributes to the development of constructive working relationships, and external - the openness of the enterprise for cooperation, adaptation to changes in public needs, that is, transparency is the key to the formation and established functioning of the triple system "object - project - investor".

That is, the culture of joint actions has a socio-economic nature, as well as entrepreneurial activity in general. In order for the organizational and cultural relations of the enterprise to contribute to the implementation of strategies for its functioning, namely investment, they must have the following features:

- to focus on the consumer strategies, in this case, on the investor;

- integrate the interests of the subjects of the internal and external environment of the enterprise;

- regulate partnership relations on a moral and legal basis, which is of particular importance at the pre-investment phase of the implementation of investment project proposals;

- pre-design models of personnel behavior in unordinary situations;

- create conditions for full self-realization of employees, constant professional development of the most capable persons in order to increase human capital;

- promote internal and external popularization of the brand field of the enterprise;

- create conditions for research of business processes and the level of quality of work life of employees together with leading scientists and consulting firms;

- increase the importance of top managers as leaders of the culture of joint actions.

The implementation of the proposed features of organizational culture will mitigate the implementation of strategic transformations, which in most cases accompany the implementation of strategies and essentially should be generated in the process of its formation. In turn, strategic reorganization significantly affects the use of the main production resource - human capital, and at the same time its success depends on the level of personnel perception of necessity and feasibility of 
transformations.

An important component of organizational and cultural relations, which constitute one of the components of the susceptibility of the enterprise to the reorganization of entrepreneurial activity, is the motivation of staff to fruitful work, the perception of organizational transformations, which are a companion to the implementation of introduced general economic, competitive, functional strategies and, first of all, one of the main - entrepreneurial. The process of motivation formation is associated with the implementation of measures that would have a direct connection with the achieved results and based on the existing active needs of staff, taking into account the interests of employees as the main productive force of enterprises in the post-industrial society. In the theory of management, motivation for high-performance work is understood as a managerial process for the formation of such a system of labour motives of the object of management, that is, personnel that ensures the effectiveness of labour behavior in accordance with the goals set by the subject of management.

As the results of the author's own research prove, the structure, hierarchy, strength, orientation of motives and the corresponding behavior of specific persons are formed under the influence of factors such as the achieved standard of living, the structure of values that a person prefers, the norms of labour morality, ideological attitudes, some other individual characteristics of a person, such as religious beliefs, gender, age, marital status, level of education.

In general, the process of motivation of labour is under the influence of factors of economic, psychological, value influence and regulation of labour activity, which is advisable to supplement the necessary elements of coercion. In order to identify the features of material, labour and status motivation, the author conducted a survey of managers of industrial enterprises of medium and higher levels of management. The choice of these positions is due to the fact that in the process of investing on the persons occupying them, there is the greatest responsibility for the success of the implementation of business strategies. Their competence, professionalism and interest are the key to achieving the expected values by indicators of economic efficiency of investment. The results of the survey on the question of the most 
significant factors for work demonstrate that the overwhelming influence have the ability to meet material needs, as answered by $70.5 \%$ of managers of the middle level of management and $75.9 \%$ of the highest, the second place first of them gave the factor of freedom (53.6\%), and the second - career opportunities (58.6\%), the third - opportunities to develop skills and abilities (43.9\%) and career growth (37.0\%) respectively, the fourth - the degree of freedom (22.9\%) and opportunities to participate in decision-making (30.6\%), fifth - respect from colleagues (17.2\% and $18.5 \%)$ and the sixth - the ability to make decisions independently (16.3\%) and develop skills and abilities (17.9\%).

Regarding the rewards that managers of higher and middle levels of management consider to be preferable for themselves, according to the results of the survey, they received their following types (in order to reduce the significance): salary increase (76.1\% and $80.0 \%$ ), bonuses (59\% and $65.6 \%$ ), the possibility of promotion (34.2\% and 37.1\%), additional payments to wages (31.5\% and $28.0 \%$ ), further training to disclose its potential (23.2\%) and the possibility to form the goals of the organization (19.9\%), instructions to do difficult work (10.3\% and 9.5\%) and others.

The biggest difficulties that managers of middle and higher levels of hierarchy have to face in the management process are: frequent changes in laws $(73.2 \%$ and 78.1\%), insufficient awareness of legal issues (37.5\% and 48\%), lack of employees of the required qualification level (28.2\%) and lack of work experience (30\%), lack of qualified consultants (26.2\% and $20 \%$ ), lack of economic knowledge (26\%), etc.

The analysis of the results of the questionnaire made it possible to conclude that managers consider the opportunity to meet material needs in their work; this puts material motivation first in importance. The second is the status motivation, which is confirmed by their desire to make a career and participate in setting goals and generating managerial decisions, and the third, respectively, occupies the labour. In addition, the results indicate the significance for respondents-managers of all levels of current motivation, since the overwhelming types of rewards the respondents called salary increase, bonuses and surcharges. However, the vast majority of respondents understand that the action of long-term motivation factors is the most 
promising, that is, the possibility of further training, advanced qualification, delegation of additional rights and powers, promotion, so the importance of strategic (long-term) motivation is not overwhelming, but significant and significant.

Since according to the results of the survey, material motivation is preferable, it is advisable to determine the amount of the fund of material promotion of SMC depending on the peculiarities of its work in accordance with the developed system of criteria given in table 3.1.

Table 3.1

\section{Conditions and trends of changes in reward indicators of strategic management centers personnel}

\begin{tabular}{|l|l|l|}
\hline \multicolumn{1}{|c|}{ Type of SMC } & \multicolumn{1}{|c|}{ Bonus terms } & \multicolumn{1}{c|}{$\begin{array}{c}\text { Tendencies of changes in premium } \\
\text { indicators }\end{array}$} \\
\hline $\begin{array}{l}\text { 1. Discretionary } \\
\text { centre of } \\
\text { management }\end{array}$ & $\begin{array}{l}\text { 1. Targeted use of allocated } \\
\text { resources. }\end{array}$ & $\begin{array}{l}\text { 1. Compliance or saving the cost } \\
\text { estimate of operating costs. }\end{array}$ \\
\hline 2. Service centre & $\begin{array}{l}\text { 2. Non-transporting operating } \\
\text { expenses estimate }\end{array}$ & $\begin{array}{l}\text { 2. High level of labour and executive } \\
\text { discipline }\end{array}$ \\
\hline $\begin{array}{l}\text { 3. Implementation } \\
\text { centre }\end{array}$ & $\begin{array}{l}\text { 1. Lack of downtime of the } \\
\text { structural subdivisions of the } \\
\text { enterprise due to the fault of this } \\
\text { centre. }\end{array}$ & $\begin{array}{l}\text { 1. Increase the time of effective } \\
\text { operation of the equipment. }\end{array}$ \\
\hline 4. Cost centre & $\begin{array}{l}\text { 1. Execution of the production } \\
\text { program on the volume and } \\
\text { structure of production. }\end{array}$ & $\begin{array}{l}\text { 1. Execution of the planned volume of } \\
\text { production. }\end{array}$ \\
\hline 5. Revenue centre & $\begin{array}{l}\text { 2. Non-transportation of the } \\
\text { planned cost of production }\end{array}$ & $\begin{array}{l}\text { 2 Reduction or compliance with the } \\
\text { planned cost of all types of products. }\end{array}$ \\
\hline 6. Profit centre & $\begin{array}{l}\text { 1. Implementation of the sales } \\
\text { plan for certain types of products. }\end{array}$ & $\begin{array}{l}\text { 3. Compliance with high quality } \\
\text { products }\end{array}$ \\
\hline $\begin{array}{l}\text { 7. Capital } \\
\text { Investment Centre }\end{array}$ & $\begin{array}{l}\text { 2. Any compensating increase in } \\
\text { costs is allowed }\end{array}$ & $\begin{array}{l}\text { 1. Achieving or increasing the planned } \\
\text { volume of product sales }\end{array}$ \\
\hline 8. Venture Centre & $\begin{array}{l}\text { 1. Achieving the planned volume } \\
\text { of gross profit }\end{array}$ & $\begin{array}{l}\text { 1. Compliance with planned values of } \\
\text { profitability indicators }\end{array}$ \\
\hline 9. Investment Centre & $\begin{array}{l}\text { 1. Implementation of the plan of } \\
\text { capital investments. }\end{array}$ & \begin{tabular}{l} 
1. Compliance with the cost estimate. \\
\hline
\end{tabular} \\
\hline
\end{tabular}

According to the given system, a small number of criteria are offered for each center (an average of 2-3 for each SMC). This offer is of fundamental importance, because when they increase, the visibility of the bonus system connection with the main results of SMC activity is lost.

The size of the fund of financial incentives should depend entirely on the 
parameters of economic efficiency of SMC and the enterprise as a whole, taking into account the contribution of each center to the results of its work. Therefore, it is advisable to divide all centers into three groups depending on the level of independence at the disposal of economic resources, which they are endowed with a central control apparatus, namely: non-self-sustaining, whose activities are completely subordinated to the enterprise; relatively independent, which the company sets planned tasks and a certain range of restrictions in the use of resources allocated to them; independent, which the company provides complete freedom of action and establishes only a limited range of indicators of the final results of their activities.

To award SMC teams of the first group, who do not have a dos-dad level of independence at the disposal of financial funds, namely discretionary, service, implementation, central management apparatus; it is advisable to allocate a certain amount of funds from profit, the amount of which depends on the achievement of the indicators of the established quantitative value. It is also advisable to include general economic services of the management apparatus, the criteria for the work of which are the implementation of the financial plan and non-transportation of the estimate of operating costs. If at least one of these conditions fails, it is impractical to make a positive decision about the bonus of the centre.

Stimulation of the centers of the second group, which include SMC expenses, revenues and profits, when performing the established indicators, it is advisable to carry out the central control apparatus within the specified amounts, which can be increased in accordance with the achievement of the indicators of the established quantitative values:

- for cents of expenses - for reducing actual costs;

- for revenue centers - for exceeding the amount of income;

- for profit centers - for increasing the amount of profit received.

Strategic centers that are part of the third group, which is characterized by a high level of independence in making managerial decisions on almost the whole range of economic issues related to their own functioning (capital investment centers, venture capital and investments), it is advisable to make bonuses completely at the 
expense of the additional funds earned by them according to the final results of their activities without restrictions from the central management apparatus.

The most important component of the creation of a premium system is the justification of the sizes of bonuses in order to ensure that the size of the promotion of the value of the labour contribution of the team is consistent. When solving this problem, the following factors should be taken into account:

- the value of a specific indicator for solving production problems;

- the number of simultaneously used indicators, their initial quantitative parameters and objectively existing possibilities for further improvement;

- labour intensity increase per unit.

- In the process of using several premium indicators, most of the bonus should account for an indicator whose improvement requires more labour effort or is more important for the implementation of the strategy. If it is impossible to compare the complexity of achieving certain indicators, it is advisable to use the method of expert assessment.

Of particular importance in the process of strategic reorganization is the solution of the problem of motivation of top managers of the enterprise and SMC in order to increase their interest in the success of its implementation in accordance with the selected set of strategic alternatives for the functioning of the business entity. Recently, large foreign companies Oracl, Chevron, LUKOIL, Yukos, Tatnafta, Gazprom use a wide range of methods to stimulate their work, among which are the most popular phantom programs for the sale or provision of option shares, a model of economic and shareholder value added to the business entity, which are modern modifications Their amount is a percentage of the actual amount of economic profit of the enterprise or its business unit expected (established or required).

Taking into account the above proposals, you can propose the following provisions on the material motivation of top managers.

1. All types of rewards should be divided into:

basic, which includes the amount of wages, which must be unchanged and do not depend on the results of the enterprise or SMC;

- additional short-term - bonuses and bonuses that should be used as a reward 
for the result of achieving the expected values of criteria and constitute a percentage: from the accounting value of the enterprise or unit, which is the difference between their assets and liabilities, or from net profit;

- additional long-term - transfer of ownership share of the enterprise, application of option programs, insurance of managers from charges in case of violation of duties, provision of long-term loans that may be interest-free or with preferential interest, the reduction of which is advisable to put in line with the change in the index of criteria of the enterprise or SMC.

2. For managers of the highest level of management of the enterprise, it is advisable to apply the same signs of bonuses as an increase in the accounting value, as well as the cost or strength of its brand.

3. For managers of the middle level of management, namely SMC, it is advisable to apply the following features: for SMC discretionary and service - the volume of services or manufactured products; for SMC sales - the value of the brand of products, the volume of its sale; for SMC expenses, income and profits - the brand value of products, the volume of gross or net profit; for SMC investments - the strength of the product brand, the accounting value of the centre, gross profit, the return of the invested capital; for venture SMC - gross profit taking into account the level of risk; for SMC investments - value and strength of brand products, accounting value of the centre, net profit, profitability of invested capital.

The practical use of recommendations for the implementation of motivation of the personnel of the enterprise as a whole and its business units - the strategic of business centers in the process of strategic reorganization will reduce the resistance to the proposed changes, which will contribute to the implementation of the formed strategies of functioning and development of the enterprise, the effective use of investment resources of the system "object - project - investor".

\section{CONCLUSIONS}

Social and labour relations in the process of entrepreneurial activity should be 
maintained on the basis of a sustainable organizational culture, which has a strategic basis.

An important component of the development of entrepreneurial activity, taking into account its social orientation, is organizational and cultural relations with subjects of the external and internal environment, having a dual meaning, which is that organizational culture as has a direct impact on the activity of investment processes, It itself is the object of investment, because it requires financial support for its development and the acquisition of a sign of adequacy to the rapidly changing conditions for the functioning of business entities. Organizational and cultural relations have a socio-economic nature, manifested in the culture of contracts and the culture of joint actions of personnel and subjects of the external environment.

The main types of contract culture of the enterprise, which should be considered to a greater extent as a system of its behavioral relationships with the environment of life, are: lobbying, active (infrastructural), corrupt, fairway (redistribution), transformational. The main goal of the culture of contracts is to obtain investment resources from the environment, the creation and successful functioning of the triple system "object - project - investor," so it should mainly be focused on efficiency and economic result, based on rational needs and a limitedrational type of behavior.

The culture of joint actions is aimed mainly at the internal environment of the enterprise, focused on the staff, its personal characteristics, individual and group needs, and through them - at achieving the expected economic result of entrepreneurial activity. Therefore, its basis is social needs, which are overwhelming, but not the most important because of the low financial security of most workers. In its essence, the culture of joint actions performs integrative, regulatory, vocational and educational functions.

The main types of culture of interaction between SMC and CA should be chosen according to the level of their independence in relation to management decisions: for centers of discretionary, service and implementation can be recommended bureaucratic; for SMC expenses, income, profit - organic; for centers of investment, venture capital and investment - entrepreneurial, and in general for 
the enterprise in the process of formation and implementation of strategies participative. A set of types of cultures of individual centers form a holistic phenomenon that characterizes a specific system of norms and rules or culture of interaction between subdivisions (joint actions), characteristic of a particular business entity, which indicates the level of its institutionalization.

Based on the results of the survey of personnel of industrial enterprises, we can conclude that in the present conditions, material stimulation is the most effective tool of motivation. To motivate employees of each SMC, it is advisable to use criteria that take into account the level of independence of the centers and the results achieved. Most of the award should account for the most important or timeconsuming indicator for the implementation of the strategy. To motivate top managers of the enterprise and its business units, it is advisable to use indicators of their accounting value, as well as the cost and strength of brands as one of the types of investment resources in the post-industrial economy.

\section{REFERENCES}

1. Ageev A., Grachev M., Kuzin D. Entrepreneurship: the strategy of the new generation // International Economics and International Relations. - 9991. - № 3. - P. 121.

2. Apresyan R. Value controversies of entrepreneurship // Social sciences and modernity. - 1993. - № 2. - P. 23.

3. Becker S.G Human behavior: an economic approach. Selected works on economic theory. M., 2003. - $672 \mathrm{c}$.

4. Buzgalin AV, Kolganov AI Global capital. - M., 2004. - 245 c.

5. Gitelman LD Transformational Management: A Textbook. - M., 1999. - 496 c.

6. Grachev MV Superframes. Personnel management in an international corporation. - M., 1993. $-207 \mathrm{c}$.

7. Grishnova OA Labour Economics and socio-labour relations: Textbook. - K., 2004. $-535 \mathrm{c}$.

8. Grishnova OA Human capital: formation in the system of education and training. - K .: Society "Knowledge", KOO, 2001. - 254 p.

9. Dyba MI, Danyliuk IV Theoretical and practical aspects of entrepreneurship // marketing in Ukraine. - 2001. - № 2. - P. 22 - 23. 
10. Dobrynin AI, Dyatlov SA. Tsyrenova ED Human capital in a transitive economy: formation, evaluation, efficiency. 1999. - 309 c.

11. Kolesnikova L., Perekrestov V. Organizational structures and culture of entrepreneurship // Questions of economics. - 2000. - № 8. - P. 15 - 30.

12. Kredisov VA Entrepreneurship - a decisive factor in the development of countries with economies in transition. - Kyiv: Knowledge of Ukraine, 2003. - 327 p.

13. Lafta JK The effectiveness of organizational management: A textbook. - M., 1999. - 320 c.

14. Makeeva VG Culture of entrepreneurship. - M .: INFRA-M, 2002. - 218 p.

15. Entrepreneurship / MG Lapusta, AG Porshnev, Yu. L. Starostin. - M .: INFRA-M, 2000. 448 p.

16. Entrepreneurship. Socio-economic management / Ed. NV Rodionova, O. O. Chitanava. - M .: UNITI-DANA, Edinstvo, 2002. - 383 p.

17. Ryvkina R. Economic sociology of transitional Russia. People and reforms. - М .: Дело, 1998. -315 c.

18. Ruttinger R. The culture of entrepreneurship. - M., 1992. - 357 c.

19. Saniakhmetova N. Signs of entrepreneurship // Entrepreneurship, economy and law. - 2001. № 8 . - P. 6 - 8.

20. Socio-economic problems and prospects for business development: Monograph. - Donetsk: LLC "South-East, LTD", 2006. - 430 p.

21. Taranukha Yu. V. Enterprise and entrepreneurship in a transforming economy. - M .: Publishing House "Business and Service", 2003. - 368 p.

22. Tomilov VV Culture of entrepreneurship. 2000. - 368 c.

23. Taranukha Yu. V. Enterprise and entrepreneurship in a transforming economy. - M .: Publishing House "Business and Service", 2003. - 368 p.

24. Tomilov VV Culture of entrepreneurship. - SPb: Piter, 2000. - 368 c.

25. Uzunov V. Entrepreneurial activity as a form of production relations of a market economy // East. - 2001. - № 1 (38). - C. 6 - 11.

26. Finagina OV Culture of entrepreneurship and the development of market relations in Ukraine // Problems of improving the efficiency of enterprises of various forms of ownership: Sb. scientific tr. / Redcol. Buleev IP (ed.) And others - Donetsk: NAS of Ukraine. Institute of Industrial Economics, 2004. - P. 175 - 181.

27. Khrutsky V. Abstract of Peter Drucker's article "Labour and management in the modern world" // Russian Economic Journal. - 1993. - № 5. - P. 74. 